\begin{tabular}{|c|c|}
\hline 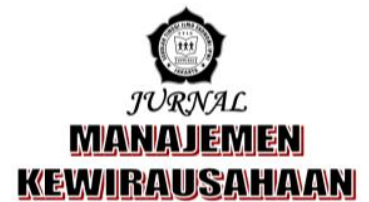 & $\begin{array}{r}\text { p-ISSN 1858-1048 } \\
\text { e-ISSN 2654-9247 } \\
\text { http://ejurnal.stieipwija.ac.id/index.php/jmk } \\
\text { DOI: http://dx.doi.org/10.33370/jmk.v17i1.382 } \\
\text { Jurnal Manajemen Kewirausahaan Vol. 17 No. 01 - Juni } 2020 \\
\text { Submit: 18 Mar 2020; Review: 11 Apr 2020; Publish: 30 Jun } 2020\end{array}$ \\
\hline
\end{tabular}

\title{
PENGARUH KUALITAS PRODUK, KUALITAS LAYANAN, DAN HARGA TERHADAP KEPUASAN PELANGGAN AIR MINUM DALAM KEMASAN
}

\section{(THE INFLUENCE OF PRODUCT QUALITY, SERVICE QUALITY, AND PRICE ON CUSTOMER SATISFACTION OF BOTTLED DRINKING WATER)}

\author{
Oleh: \\ Rizka Bayu Aditya \\ bayu6101@gmail.com \\ STKIP Kumala Lampung
}

\begin{abstract}
Customer satisfaction is defined as customer responses to a mismatch between the importance of earlier and actual performance had felt after use. This research was conducted at PT Tirta Kencana Mekar Tangerang by distributing questionnaires to bottled drinking water consumers (AMDK) which was 43 respondent samples, then analyzed by using quantitative data analysis. Quantitative analysis includes test validity and reliability, classic assumption test, multiple regression analysis, hypothesis testing through $t$-test and $f$-test, and determination coefficient analysis (R2). Hypothesis testing using the t-test showed that three independent variables studied proved to affect customer satisfaction variable. With an f-test can be seen that the variable product quality, price, and service is indeed feasible to test the customer satisfaction variable. Adjusted $R$ Square indicates that $57.7 \%$ of customer satisfaction can be explained by the three independent variables in the regression equation. While the rest of $42.3 \%$ percent is explained by others research.
\end{abstract}

Keywords: Quality Products, Quality Service, Price, Customer Satisfaction

\begin{abstract}
ABSTRAK
Kepuasan pelanggan, sangat dipengaruhi oleh kualitas layanan, serta ditentukan oleh kualitas harga dan produk. Penelitian ini dilaksanakan di PT Tirta Kencana Mekar Tangerang dengan menyebarkan kuesioner kepada pelanggan air minum dalam kemasan (AMDK) yang berjumlah 43 sampel responden, kemudian dilakukan analisis data secara kuantitatif, yaitu uji validitas dan reliabilitas, asumsi klasik serta analisis regresi berganda, dimana pengujian hipotesis melalui uji $t$ dan uji $F$, kemudian dilakukan analisis koefisien determinasi. Hasil dari pengujian hipotesis ditemukan terdapat tiga variabel independen yang diteliti terbukti secara mempengaruhi variabel kepuasan pelanggan. Kemudian setelah melalui uji $F$ diketahui pula bahwa variabel kualitas produk, harga, dan layanan memang layak dalam menguji variabel kepuasan pelanggan. Angka adjusted $R$ square menunjukan bahwa 57,7\% kepuasan pelanggan dapat dijelaskan oleh ketiga variabel independen dalam persamaan regresi. Sedangkan sisanya sebesar 42,3\% dijelaskan oleh variabel lain di luar penelitian ini.
\end{abstract}

Kata Kunci: Kualitas Produk, Harga, Layanan 


\section{PENDAHULUAN}

Persaingan bisnis menjadi semakin tajam, baik pasar untuk domestik maupun pasar global dalam era globalisasi saat ini. Dimana pelanggan tetap ada namun sayangnya daya beli mereka semakin menurun. Sehingga pelanggan menjadi semakin kritis dalam melakukan pembelian terhadap sebuah produk yang mereka konsumsi. Keadaan tersebut membuat perusahaan dituntut bekerja secara optimal dan profesional agar dapat bersaing dan bertahan dengan produk yang mereka miliki. Setiap perusahaan harus mampu menarik pelanggan dengan menawarkan produk yang berkualitas tingi dengan harga yang ekonomi dan pelayanan yang baik.

Perusahaan akan maju jika mengutamakan kepuasan bagi para pelanggan. Apabila perusahaan melakukan suatu kesalahan yang dapat merugikan pelanggan maka hal ini akan menimbulkan dampak yang tidak bagi perusahaan sebab pelanggan akan meninggalkan perusahaan dan menjadi pelanggan dari perusahaan yang lain. Sebagaimana hal tersebut ditetapkan dalam Undang-Undang Republik Indonesia Nomor 8 Tahun 1999 tentang Perlindungan Konsumen yang mencakup Hak dan Kewajiban Konsumen Pasal 4 ayat b bahwa hak untuk memilih barang dan atau jasa serta mendapatkan barang dan atau jasa tersebut sesuai dengan nilai tukar dan kondisi serta jaminan yang di janjikan

Dalam pemasaran terdapat beberapa konsep kepuasan pelanggan yang digunakan untuk menilai seorang pelanggan itu merasa puas atau tidak yaitu: a) Positive Disconfirmation, hasil yang didapat lebih baik dari hasil yang diharapkan. b) Simple Disconfirmation, hasil yang didapat sama dengan hasil yang diharapkan. c) Negative Disconfirmation, hasil yang didapat lebih buruk dari hasil yang diharapkan.
Gambar 1

Konsep Kepuasan Konsumen

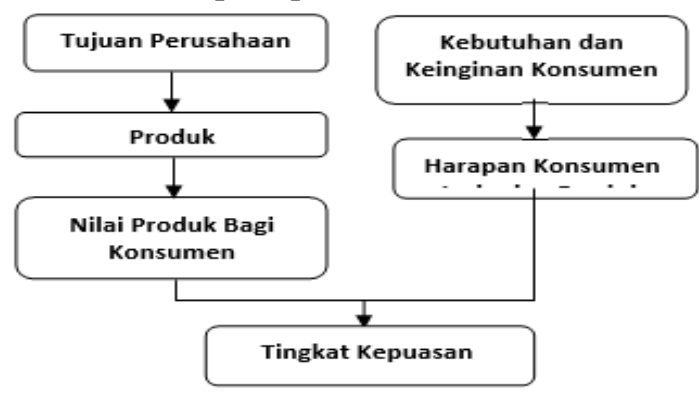

Gambar 2

Grafik Jumlah Pelanggan AMDK Tahun 2011-2015

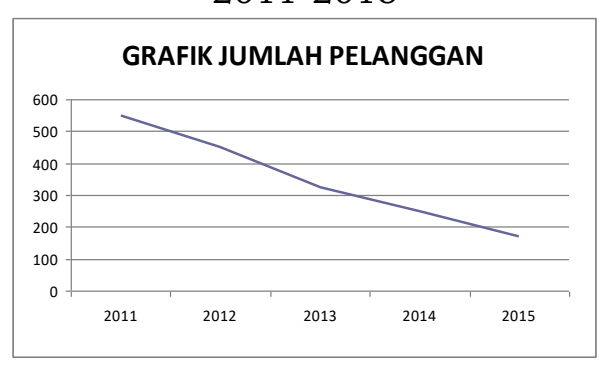

Dari gambar 2 dapat dilihat bahwa setiap tahunnya jumlah pelanggan air minum dalam kemasan (AMDK) Air Hidup mengalami penurunan di setiap tahunnya dan hal ini harus ditanggapi serius oleh pihak PT Tirta Kencana Mekar Tangerang supaya tidak terjadi masalah yang berlarut-larut tentu saja dalam hal kepuasan pelanggan.

Hasil kajian penelitian terdahulu juga menunjukkan adanya hasil penelitian yang berbeda tentang pengaruh kualitas produk, kualitas layanan, dan harga terhadap kepuasan pelanggan air minum dalam kemasan, yaitu hasil penelitian yang pengaruhnya signifikan (Wardhani (2010), Amir (2012), Adi (2012), Putri (2012), Fardiani (2013), Ardhana (2010), Rahman (2013), Erviana (2013), Subaidi (2008), dan Sudirman (2011).

Wardhani (2010) menganalisis pengaruh kualitas produk, kualitas layanan dan nilai konsumen terhadap kepuasan konsumen kedai digital di Semarang menyatakan bahwa, kualitas produk, kualitas layanan dan nilai konsumen berpengaruh terhadap kepuasan konsumen.

Fachruzi Amir (2012) menganalisis faktor-faktor yang mempengaruhi 
kepuasan konsumen pada PT. Hasjrat Abadi di Makassar menyatakan bahwa kualitas produk, kualitas pelayanan, harga, dan promosi berpengaruh terhadap kepuasan konsumen.

Albertus Ferry Rostya Adi (2012) menganalisis pengaruh harga, kualitas produk, dan kualitas layanan terhadap kepuasan konsumen Warung Spesial Sambal cabang lampersari di Semarang menyatakan bahwa harga, kualitas produk, dan kualitas layanan berpengaruh terhadap kepuasan konsumen.

Putri (2012) menganalisis pengaruh bauran pemasaran terhadap kepuasan pelanggan di Toko Dannis Collection Pati menyatakan bahwa produk, harga, lokasi, promosi berpengaruh terhadap kepuasan pelanggan.

Fardiani (2013) menganalisis pengaruh kualitas pelayanan, harga, dan promosi terhadap kepuasan pelanggan Dyriana Bakery \& Café Pandanaran Semarang menyatakan bahwa kualitas pelayanan, harga, dan promosi berpengaruh terhadap kepuasan pelanggan.

Ardhana (2010) menganalisis pengaruh kualitas pelayanan, harga dan lokasi terhadap kepuasan pelanggan (Studi Pada Bengkel Caesar Semarang) menyatakan bahwa kualitas pelayanan, harga dan lokasi berpengaruh terhadap kepuasan pelanggan.

Rahman (2013) menganalisis pengaruh kualitas pelayanan, fasilitas, persepsi harga dan lokasi terhadap kepuasan konsumen pada Pemancingan Ngrembel Asri Gunungpati Semarang menyatakan bahwa kualitas pelayanan, fasilitas, persepsi harga dan lokasi berpengaruh terhadap kepuasan konsumen.

Erviana (2013) menganalisis pengaruh kualitas pelayanan dan kepercayaan terhadap kepuasan pasien rawat inap di RSUD dr. Soewondo Kendal menyatakan bahwa kualitas pelayanan dan kepercayaan berpengaruh terhadap kepuasan pasien.

Subaidi (2008) dalam penelitian tentang pengaruh kualitas layanan terhadap kepuasan pelanggan pada usaha jasa internet zaisya net di malang menyatakan bahwa kualitas layanan berpengaruh terhadap kepuasan pelanggan.

Sudirman (2011) menganalisis pengaruh kualitas pelayanan terhadap kepuasan konsumen produk tabungan britama pada PT. Bank Rakyat Indonesia (persero) tbk cabang A. Yani makassar menyatakan bahwa kualitas pelayanan berpengaruh terhadap kepuasan konsumen

Hipotesis yang diuji dalam penelitian ini adalah: a. kualitas produk, harga dan layanan, berpengaruh secara simultan terhadap kepuasan konsumen air minum dalam kemasan. b. kualitas produk, harga dan layanan berpengaruh secara parsial terhadap kepuasan konsumen air minum dalam kemasan

Gambar 3

Model Penelitian

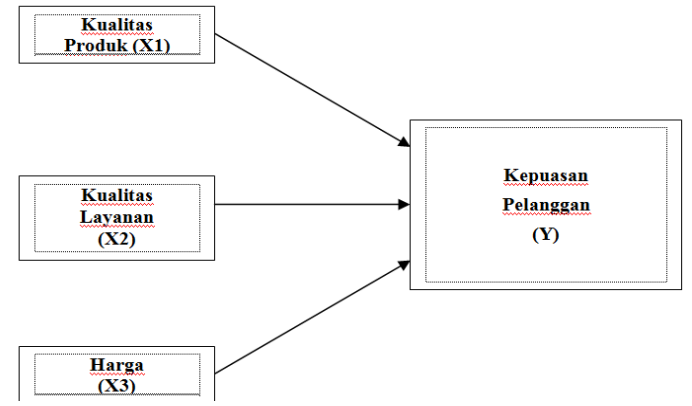

\section{METODE PENELITIAN}

Populasi sasaran yang diteliti adalah pelanggan air minum dalam kemasan tahun 2015 yang berjumlah 170 pelanggan, maka jumlah sampel yang diambil berjumlah 43 orang atau $25 \%$ dari jumlah populasi, dengan demikian penelitian ini disebut dengan penelitian populasi sejumlah 43 orang Metode analisis data yang digunakan adalah analisis regresi linier berganda dengan persamaan model sebagai berikut:

$$
\mathrm{Y}=\alpha+\beta 1 . \mathrm{X} 1+\beta 2 . \mathrm{X} 2+\beta 3 . \mathrm{X} 3+\mathrm{e}
$$

$\mathrm{Y}=$ kepuasan pelanggan

$\beta 1=$ koefisien regresi kualitas produk.

$\beta 2=$ koefisien regresi kualitas layanan.

$\beta 3=$ koefisien regresi harga.

$\mathrm{X} 1=$ kualitas produk

$\mathrm{X} 2$ = kualitas layanan 
X3 = harga

$\alpha=$ konstanta

$\mathrm{e}=$ standar eror .

Untuk dapat menguji pengaruh semua variabel independen secara simultan terhadap variabel dependen menggunakan uji $\mathrm{F}$ dengan hipotesis yaitu: a) Menentukan Formulasi, Ho : b1 $=\mathrm{b} 2=\mathrm{b} 3=\ldots \ldots \ldots \ldots=\mathrm{bk}=0$. Artinya adalah apakah semua variabel independen bukan merupakan penjelas yang signifikan terhadap variabel dependen. Ha: $\mathrm{b} 1 \neq \mathrm{b} 2 \neq \mathrm{b} 3 \neq$

$\neq \mathrm{bk} \neq 0$. Artinya adalah, semua variabel independen secara simultan merupakan penjelas yang signifikan terhadap variabel dependen.

b) Menentukan Derajat Kepercayaan $5 \%(a=0,05)$ dari $\mathrm{F}$ hitung dan $\mathrm{F}$ tabel. Bila F hitung > F tabel maka Ho ditolak dan $\mathrm{Ha}$ diterima yang menyatakan bahwa semua variabel independen secara serentak serta signifikan mempengaruhi variabel dependen. Bila $F$ hitung < F tabel maka Ho diterima dan Ha ditolak, yang menyatakan bahwa semua variabel independen secara serentak serta signifikan tidak mempengaruhi variabel dependen.

c) Membuat Kesimpulan yaitu bila $\mathrm{F}$ hitung $>\mathrm{F}$ tabel maka Ho ditolak dan $\mathrm{Ha}$ diterima. Bila $\mathrm{F}$ hitung $<\mathrm{F}$ tabel maka Ho diterima dan Ha ditolak

Untuk dapat menguji pengaruh setiap variabel independen secara parsial terhadap variabel dependen digunakan uji t dengan hipotesis yaitu: a) Menentukan Formulasi Hipotesis, Ho : $\mathrm{b} 1: \mathrm{b} 2: \mathrm{b} 3=0$. Artinya adalah variabel independen bukan merupakan penjelas yang signifikan terhadap variabel dependen. Ha $: \mathrm{b} 1: \mathrm{b} 2: \mathrm{b} 3 \neq 0$. Artinya adalah variabel independen merupakan penjelas yang signifikan terhadap variabel dependen.

b) Menentukan Derajat Kepercayaan $5 \%(\alpha=0,05)$ dari t hitung dan t tabel, apabila $\mathrm{t}$ hitung $>\mathrm{t}$ tabel maka Ho ditolak dan Ha diterima, apabila t hitung $<\mathrm{t}$ tabel maka Ho diterima dan $\mathrm{Ha}$ ditolak.

c) Membuat Kesimpulan yaitu bila $t$ hitung > t tabel maka Ho ditolak dan Ha diterima, yang menyatakan bahwa variabel independen secara individual mempengaruhi variabel dependen. Bila $t$ hitung < t tabel maka Ho diterima dan Ha ditolak, yang menyatakan bahwa variabel independen secara individual tidak mempengaruhi variabel dependen.

Dalam analisis ini disertakan dengan pengukuran koefisien determinasi (R2) yang dapat mengukur seberapa besar kemampuan model dalam menjelaskan variasi kepuasan konsumen. Nilai koefisien determinasi adalah antara 0 dan 1. Nilai R2 yang kecil, yaitu mendekati 0 , menunjukkan kemampuan yang amat terbatas dari variabel-variabel independen dalam menjelaskan variasi variabel dependen. Sedangkan nilai R2 yang besar, yaitu mendekati 1, berarti variabel-variabel independen memberikan hampir seluruh informasi yang diperlukan untuk memprediksi variasi variabel dependen (Ghozali, 2007).

\section{HASIL PENELITIAN Hasil Uji Validitas}

Tabel 1

Uji Validitas

\begin{tabular}{|c|c|c|c|c|}
\hline Variabel & No. Item & $\mathrm{r}$ hitung & $\mathrm{r}$ tabel & Kriteria \\
\hline \multirow{4}{*}{$\begin{array}{c}\text { Kualitas Produk } \\
\text { (X1) }\end{array}$} & 1 & 0,582 & 0,301 & Valid \\
\cline { 2 - 5 } & 2 & 0,479 & 0,301 & Valid \\
\cline { 2 - 5 } & 3 & 0,551 & 0,301 & Valid \\
\cline { 2 - 5 } & 4 & 0,468 & 0,301 & Valid \\
\cline { 2 - 5 } & 5 & 0,624 & 0,301 & Valid \\
\hline \multirow{4}{*}{$\begin{array}{c}\text { Kualitas Layanan } \\
\text { (X2) }\end{array}$} & 1 & 0,653 & 0,301 & Valid \\
\cline { 2 - 5 } & 2 & 0,593 & 0,301 & Valid \\
\cline { 2 - 5 } & 3 & 0,308 & 0,301 & Valid \\
\cline { 2 - 5 } & 4 & 0,577 & 0,301 & Valid \\
\hline \multirow{4}{*}{$\begin{array}{c}\text { Harga } \\
\text { (X3) }\end{array}$} & 5 & 0,696 & 0,301 & Valid \\
\cline { 2 - 5 } & 2 & 0,659 & 0,301 & Valid \\
\cline { 2 - 5 } & 3 & 0,374 & 0,301 & Valid \\
\cline { 2 - 5 } & 4 & 0,545 & 0,301 & Valid \\
\cline { 2 - 5 } & 5 & 0,680 & 0,301 & Valid \\
\hline \multirow{4}{*}{$\begin{array}{c}\text { Kepuasan Pelanggan } \\
\text { (Y) }\end{array}$} & 1 & 0,615 & 0,301 & Valid \\
\cline { 2 - 5 } & 2 & 0,520 & 0,301 & Valid \\
\cline { 2 - 5 } & 3 & 0,391 & 0,301 & Valid \\
\cline { 2 - 5 } & 4 & 0,401 & 0,301 & Valid \\
\cline { 2 - 5 } & 5 & 0,599 & 0,301 & Valid \\
\hline
\end{tabular}

\section{Hasil Uji Reliabilitas}

Tabel 2

Uji Reliabilitas

\begin{tabular}{|c|c|c|}
\hline Variabel & $\begin{array}{c}\text { Cronbach } \\
\text { Alpha }\end{array}$ & Kriteria \\
\hline Kualitas Produk (X1) & 0,610 & Reliabel \\
\hline Kualitas Layanan (X2) & 0,715 & Reliabel \\
\hline Harga (X3) & 0,636 & Reliabel \\
\hline Kepuasan Pelanggan (Y) & 0,639 & Reliabel \\
\hline
\end{tabular}


Uji reliabilitas menunjukkan bahwa nilai Cronbach Alpha dari tiap-tiap konstruk atau variabel lebih besar dari 0,60 yang berarti bahwa kuesioner yang merupakan indikator-indikator dari variabel tersebut adalah reliabel. Hal ini dapat dilihat dari hasil pengujian yang telah dilakukan sebagai berikut: variabel Kualitas Produk (X1) nilainya sebesar 0, 610, Layanan (X2) sebesar 0, 715, Harga (X3) sebesar 0, 636, dan Kepuasan Konsumen (Y) sebesar 0, 639.

\section{Hasil Linier Berganda}

Tabel 3

Uji Regresi

Coefficients"

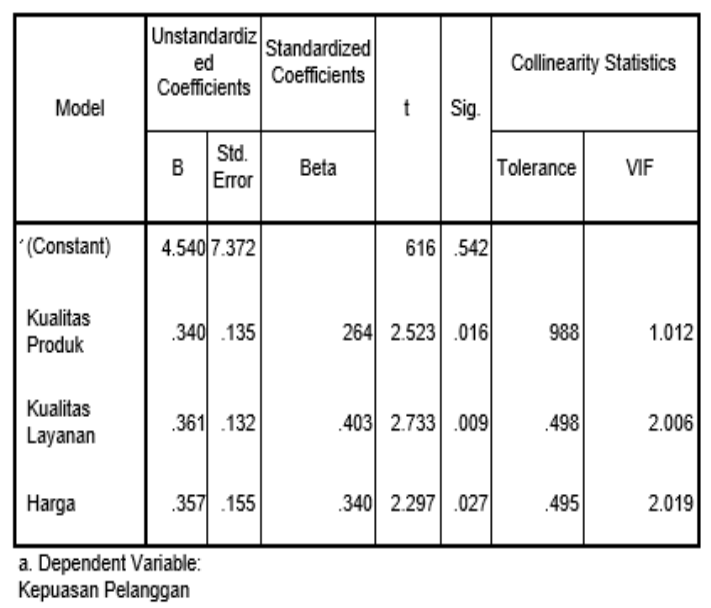

Berdasarkan tabel mengenai hasil estimasi regresi linear berganda dengan program SPSS for windows, maka diperoleh persamaan regresi linear berganda dalam penelitian yaitu $\mathrm{Y}=$ 0,264.X1 + 0,403.X2 + 0, 340.X3

dimana:

$\mathrm{Y}=$ Kepuasan Konsumen

$$
\begin{aligned}
& \text { X1 = Kualitas Produk } \\
& \text { X2 = Kualitas Layanan } \\
& \text { X3 = Harga }
\end{aligned}
$$

Variabel Kualitas Produk (X1) berpengaruh positif terhadap Kepuasan Konsumen (Y) dengan nilai 0,264. Variabel Layanan (X2) berpengaruh positif terhadap Kepuasan Konsumen (Y) dengan nilai 0,403. Variabel Harga (X3) berpengaruh positif terhadap Kepuasan Konsumen (Y) dengan nilai 0,340.

Hasil perhitungan koefisien regresi dengan uji $t$ adalah nilai t hitung pada variabel kualitas produk (X1) adalah sebesar 2,523 dengan tingkat signifikansi 0,016. Karena $\mathrm{t}$ hitung $>\mathrm{t}$ tabel dengan tingkat signifikansi 0,016 < 0,05 maka Ho ditolak dan Ha diterima, kemudian nilai $t$ hitung pada variabel Layanan (X2) adalah sebesar 2,733 dengan tingkat signifikansi 0,009. Karena t hitung $>\mathrm{t}$ tabel dengan tingkat signifikansi $0,009<0,05$ maka Ho ditolak dan $\mathrm{Ha}$ diterima, dan Nilai $\mathrm{t}$ hitung pada variabel harga (X3) adalah sebesar 2,297 dengan tingkat signifikansi 0,027. Karena thitung $<\mathrm{t}$ tabel dengan tingkat signifikansi $0,027<$ 0,05 maka Ho diterima dan Ha ditolak.

\section{Hasil Estimasi Linier Berganda (Uji F)}

\begin{tabular}{|l|r|r|r|c|c|} 
Tabel 4 \\
ANOVA \\
\hline \multicolumn{1}{|c|}{ Model } & Sum of Squares & df & Mean Square & F & Sig. \\
\hline Regression & 262.280 & 3 & 87.427 & 17.711 & $.000^{\mathrm{a}}$ \\
Residual & 192.511 & 39 & 4.936 & & \\
Total & 454.791 & 42 & & & \\
\hline
\end{tabular}

a. Predictors: (Constant), Harga, Kualitas Produk, Kualitas Layanan b. Dependent Variable: Kepuasan Pelanggan

Berdasarkan uji ANOVA atau F test, maka dapat diperoleh Fhitung sebesar 17,711 dengan tingkat signifikansi 0,000 . Oleh karena probabilitas jauh lebih kecil daripada 0,05 (0,000 lebih kecil dari 0,05) dan Fhitung lebih besar dari Ftabel, maka dapat dinyatakan bahwa variabel independen yang meliputi kualitas produk (X1), kualitas layanan (X2), dan harga (X3) secara simultan atau bersama-sama mempengaruhi variabel kepuasan pelanggan $(\mathrm{Y})$.

\section{Koefisien Determinasi}

Tabel 5

Model Summary ${ }^{\circ}$

\begin{tabular}{|l|r|r|r|r|r|}
\hline Model & \multicolumn{1}{|c|}{$\mathrm{R}$} & R Square & Adjusted R Square & $\begin{array}{r}\text { Std. Error of } \\
\text { the Estimate }\end{array}$ & $\begin{array}{c}\text { Durbin- } \\
\text { Watson }\end{array}$ \\
\hline 1 & $.759^{\mathrm{a}}$ & 577 & .544 & .2 .222 & 2.057 \\
\hline
\end{tabular}

a. Predictors: (Constant), Harga, Kualitas Produk, Kualitas Layanan b. Dependent Variable: Kepuasan Pelanggan

Dari tabel terlihat tampilan output SPSS model summary besarnya Adjusted R Square adalah 0,577. Hal ini berarti 57,7 persen variasi kepuasan pelanggan $(\mathrm{Y})$ yang dapat dijelaskan oleh variabel-variabel independen yaitu kualitas produk, kualitas layanan, dan 
harga. Sedangkan sisanya $(100 \%-57,7$ $\%=42,3 \%$ ) dijelaskan oleh sebab-sebab lainnya di luar model yang tidak diteliti dalam penelitian ini.

Tabel 6

Uji Multikolinearitas

\begin{tabular}{|c|c|c|}
\hline Variabel & Tolerance & VIF \\
\hline Kualitas Produk & 0,988 & 1.012 \\
\hline Kualitas Layanan & 0,498 & 2.006 \\
\hline Harga & 0,495 & 2.019 \\
\hline
\end{tabular}

Tabel 7

Uji Normalitas

Scatterplot

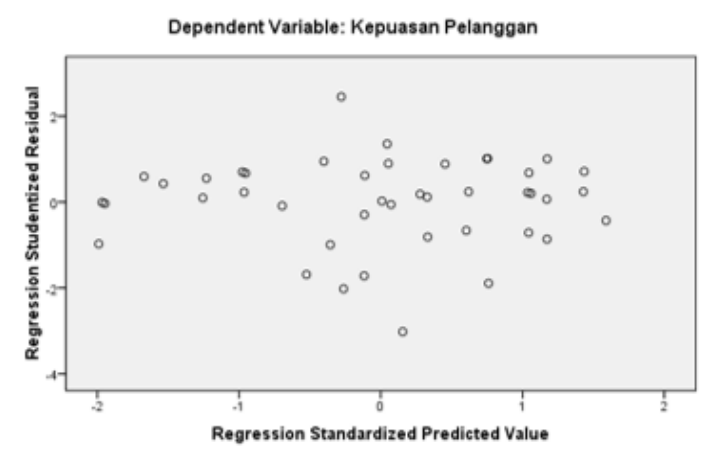

Dari gambar di atas menunjukan bahwa titik-titik menyebar secara acak dan tidak membentuk pola tertentu yang jelas, serta tersebar di atas maupun di bawah angka 0 pada sumbu Y. Hal ini menunjukan bahwa tidak ada heteroskedastisitas pada model regresi tersebut.

Temuan penelitian tentang adanya pengaruh signifikan dari kualitas produk secara parsial terhadap kepuasan pelanggan (Y) mendukung hasil penelitian Evrina Wardhani (2010), Fachruzi Amir (2012), Albertus Ferry Rostya Adi (2012), Berlian Aminanti Suraya Putri (2012), menyatakan bahwa kualitas sebuah produk dapat berpengaruh sangat signifikan secara parsial terhadap kepuasan pelanggan.

Temuan penelitian tentang adanya pengaruh signifikan dari harga (X3) secara parsial terhadap kepuasan pelanggan (Y) mendukung hasil penelitian Aprillia Nia Fardiani (2013) dan Oldy Ardhana (2010), yang menunjukkan bahwa harga (X3) berpengaruh signifikan terhadap kepuasan pelanggan (Y).

\section{KESIMPULAN Simpulan}

Uji validitas dapat disimpulkan bahwa masing-masing butir pertanyaan adalah valid. Uji reliabilitas menunjukkan bahwa kuesioner yang merupakan indikator-indikator dari variabel tersebut adalah reliabel atau handal. Dari hasil estimasi regresi linear berganda maka dapat disimpulkan untuk variabel kualitas produk berpengaruh positif terhadap kepuasan pelanggan ini dibuktikan dengan nilai 0,264 , sedangkan variabel kualitas layanan berpengaruh positif terhadap kepuasan pelanggan dengan nilai 0,403 , dan variabel harga berpengaruh positif terhadap kepuasan pelanggan dengan nilai 0,340 . Hasil uji t memperlihatkan bahwa nilai $t$ hitung pada variabel kualitas produk adalah sebesar 2,523, kemudian nilai $t$ hitung pada variabel kualitas layanan adalah sebesar 2,733 dengan tingkat signifikansi 0,009 , dan nilai $t$ hitung pada variabel harga adalah sebesar 2,297. Hasil uji F memperlihatkan bahwa variabel kualitas produk, kualitas layanan, dan harga layak untuk menguji kepuasan pelanggan sebagai variabel dependennya. Hal tersebut ditunjukan dari F hitung sebesar 17.711.

\section{Saran}

Berdasarkan kesimpulan di atas peneliti merekomendasikan beberapa saran sebagai berikut, yaitu kualitas produk merupakan kemampuan produk untuk melakukan fungsi-fungsinya dengan optimal, lebih meningkatkan kualitas produk, melakukan inovasi produk, serta melakukan pendekatan terhadap masyarakat yang belum menggunakan produk PT Tirta Kencana Mekar Tangerang. Harga lebih di sesuaikan lagi dengan daya beli masyarakat menengah ke bawah, agar semua masyarakat dapat menikmati produk PT Tirta Kencana Mekar 
Tangerang. Kualitas layanan harusnya ditingkatkan lagi dalam hal kinerja karyawan untuk melayani pelanggan lebih baik lagi. Kepuasan pelanggan terhadap PT Tirta Kencana Mekar, hendaknya lebih di perhatikan, untuk mengurangi keluhan-keluhan masyarakat terhadap produk Air Minum Dalam Kemasan (AMDK).

\section{DAFTAR PUSTAKA}

Adi, A. F. R. 2012. Pengaruh harga, Kualitas produk, dan Kualitas layanan terhadap kepuasan pelanggan (studi pada waroeng spesial sambal cabang lampersari semarang).

Amir, F., \& Amir, F. 2012. Analisis faktor-faktor yang mempengaruhi kepuasan pelanggan pada PT. Hasjrat Abadi di Makassar.

Ardhana, O. 2010. Pengaruh kualitas pelayanan, harga dan lokasi terhadap kepuasan pelanggan (studi pada bengkel caesar semarang).

Erviana, O. 2013. Pengaruh kualitas pelayanan dan kepercayaan terhadap kepuasan pasien rawat inap di RSUD dr. Soewondo Kendal.

Fardiani, A. N. 2013. Pengaruh kualitas pelayanan, harga, dan promosi terhadap kepuasan pelanggan dyriana bakery \& cafe pandanaran semarang.

Ghozali, I. 2007. aplikasi analisis multivariate dengan program SPSS. Semarang: Badan Penerbit UNDIP.

Putri, B. A. S. 2012. Pengaruh bauran pemasaran terhadap kepuasan pelanggan (studi kasus di toko dannis collection pati).

Rahman, D. N. 2013. Pengaruh kualitas pelayanan, fasilitas, persepsi harga dan lokasi terhadap kepuasan konsumen pada pemancingan ngrembel asri gunungpati semarang.

Subaidi. 2008. Pengaruh kualitas pelayanan terhadap kepuasan konsumen pada usaha jasa internet zaisya net di Malang.
Sudirman, D. Y. 2011. Pengaruh kualitas layanan terhadap kepuasan nasabah produk tabungan britama pada PT. Bank Rakyat Indonesia (persero) tbk cabang A. Yani Makassar.

Wardhani, E. 2010. Pengaruh kualitas produk, kualitas pelayanan dan nilai pelanggan terhadap kepuasan pelanggan kedai digital 23 di Semarang. 
